\title{
Novel transient alien limb phenomenon heralding a diabetic hyperosmolar non-ketotic state with leukoaraiosis: a video presentation
}

\author{
Antonio Jose Reyes, ${ }^{1}$ Kanterpersad Ramcharan, ${ }^{2,3}$ Rishi Ramtahal ${ }^{4}$
}

${ }^{1}$ Department of Medicine, Neurology Unit, San Fernando Teaching Hospital,

San Fernando, Trinidad and Tobago

${ }^{2}$ Department of Medicine, San Fernando Teaching Hospital, San Fernando, Trinidad and Tobago ${ }^{3}$ Department of Medicine, Surgi-Med Clinic, San Fernando, Trinidad and Tobago Department of Medicine, Diabetes and Endocrinology, Area Hospital Point Fortin, Point Fortin, Trinidad and Tobago

Correspondence to Dr Kanterpersad Ramcharan, kramcharan79@yahoo.com

Accepted 26 October 2015

CrossMark

\section{To cite: Reyes AJ,}

Ramcharan K, Ramtahal R. BMJ Case Rep Published online: [please include Day Month Year] doi:10.1136/ bcr-2015-212865

\section{DESCRIPTION}

A 76-year-old right-handed non-diabetic woman presented with involuntary upper left limb movements for $2 \mathrm{~h}$. The patient described the limb as

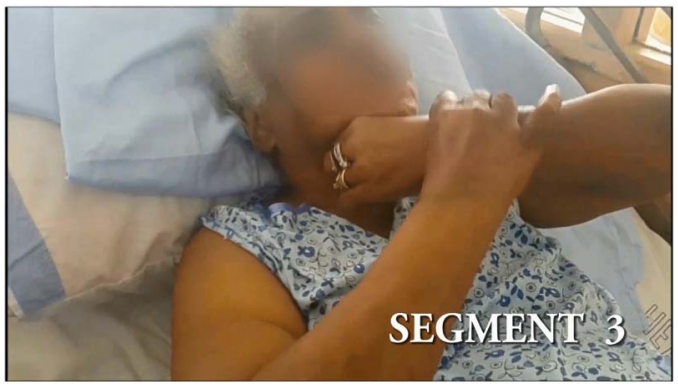

Video 1 Segments 1, 2, 3 and 4 showing intermittent levitation of the left hand, thumping of the chest, and grasping and strangling behaviour accompanied by self-inflicted abrasions of the neck, and normal state after treatment. having a will of its own. The movements occurred intermittently for 7 days, with each episode lasting 10-20 min. Segment 1 (video 1) showed levitation of the left hand with right hand restraint. Segment 2 displayed the left hand thumping the chest, with neck abrasions. Segment 3, 1 week later demonstrated neck strangulation. Segment 4, 2 weeks later exhibited normality. Physical examination revealed apraxia and dystonia but no parkinsonism. The Montreal cognitive assessment score was 25/30 due to executive impairment. The patient was dyslipidaemic with hypertensive heart disease. However, the blood sugar was $589 \mathrm{mg} / \mathrm{dL}$, glycated haemoglobin was $11.2 \%$ and serum osmolality was increased at $329 \mathrm{mOsm} / \mathrm{kg}$ water without ketonuria. Other routine blood investigations were normal. Intravenous insulin and fluids were given. MRI performed on admission showed diffuse brain atrophy on T1 (figure 1A); extensive high signals in the periventricular white matter (leukoaraiosis) in axial T2 and fluid-attenuated inversion recovery
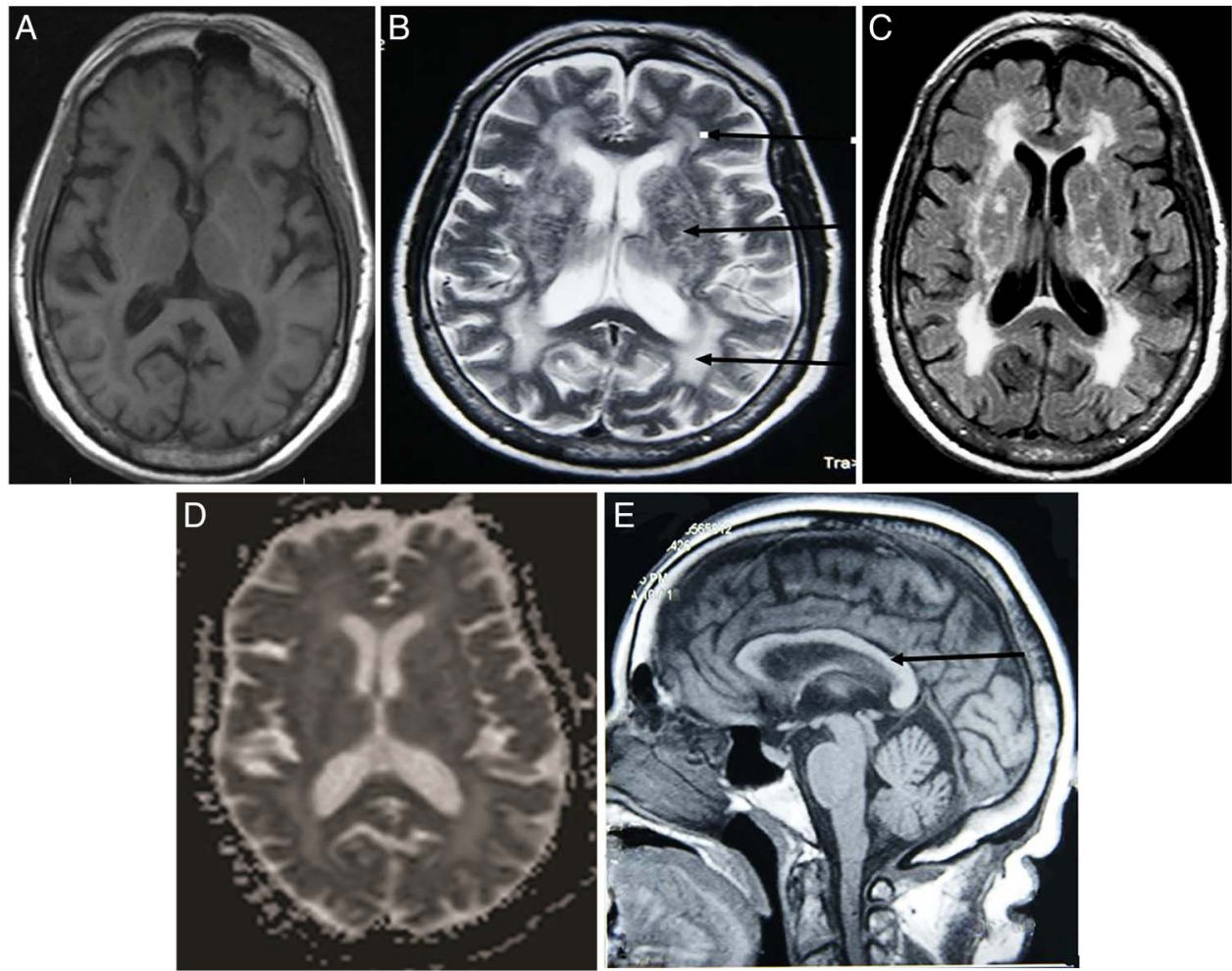

Figure 1 MRI performed on admission: (A) Axial T1-weighted MRI showing diffuse cerebral atrophy. (B) Axial T2 MRI view showing extensive periventricular hyperintensities (leukoaraiosis; see arrows). (C) Axial T2 fluid-attenuated inversion recovery MRI showing leukoaraiosis consistent with small vessel ischaemic changes. (D) Axial diffusion-weighted MRI without hyperintensities suggestive of an infarct. (E) Sagittal T1 MRI view showing an intact corpus callosum (see arrow). 
(figure 1B,C); no hyperintensities suggestive of stroke on diffusion-weighted imaging axial view (figure 1D) and intact corpus callosum in sagittal T1 view (figure 1E). MR angiography and EEG were normal. At 5 weeks, repeat MRI sequences

\section{Learning points}

- These intermittent, slow and fast jerky movements accompanied by self-inflicted injuries due to strangling, grasping, thumping with lifting and dropping the left upper limb met the classic definition of alien limb phenomenon, with unwilled and uncontrollable but seemingly purposeful movements of an upper or lower limb.

- Although dyskinesias, focal epilepsy, hemichorea-hemiballismus, asterixis and tremors have been associated with a diabetic hyperosmolar nonketotic state (DHNKS), the alien limb phenomenon has not been linked to DHNKS before.

- The pathogenesis of DHNKS-induced alien limb phenomenon is unknown but it probably implies disruption of the brain network causing loss of inhibitory tone. showed no new changes. The patient remained well 3 months later on oral hypoglycaemics, with no suggestion of corticobasal syndrome. ${ }^{1}$ Alien limb phenomenon has many clinical and radiological correlations, including leukoaraiosis. ${ }^{2}$ Damage of brain neuronal connectivity has been postulated as the pathogenic mechanism. ${ }^{3}$

Acknowledgements The authors thank Dr M Gosein, Dr R Banfield, Dr D Ojar and $\mathrm{Dr} F$ Rampersad for their contribution to the radiological aspects of the manuscript. They also thank Dr S Karim and Ms S Sealy for their contribution with the medical photography.

Contributors AJR diagnosed and managed the patient, and drafted the manuscript. KR assisted with research and preparation of the manuscript. RR managed the patient and assisted with the manuscript.

Competing interests None declared.

Patient consent Obtained.

Provenance and peer review Not commissioned; externally peer reviewed.

\section{REFERENCES}

1 Graff-Radford J, Rubin MN, Jones DT, et al. The alien limb phenomenon. J Neurol 2013:260:1880-8.

2 Gondim Fde A, Tavares Júnior JW, et al. Alien limb syndrome responsive to amantadine in a patient with corticobasal syndrome. Tremor Other Hyperkinet Mov 2015:5:1-4.

3 Sarva H, Deik A, Severt WL. Pathophysiology and treatment of alien hand syndrome. Tremor Other Hyperkinet Mov 2014:4:1-22.

Copyright 2015 BMJ Publishing Group. All rights reserved. For permission to reuse any of this content visit

http://group.bmj.com/group/rights-licensing/permissions.

BMJ Case Report Fellows may re-use this article for personal use and teaching without any further permission.

Become a Fellow of BMJ Case Reports today and you can:

- Submit as many cases as you like

- Enjoy fast sympathetic peer review and rapid publication of accepted articles

- Access all the published articles

- Re-use any of the published material for personal use and teaching without further permission

For information on Institutional Fellowships contact consortiasales@bmjgroup.com

Visit casereports.bmj.com for more articles like this and to become a Fellow 